\title{
EM DEFESA DE ADORNO: A PROPÓSITO DAS CRÍTICAS ENDEREÇADS POR GIORGIO AGAMBEN À DIALÉTICA ADORNIANA
}

\author{
Maurício Chiarello* \\ mgchiarello@bol.com.br
}

RESUMO Pensador dos mais instigantes da atualidade, Giorgio Agamben explora, em boa parte de seus ensaios filosóficos, a significação excepcional que apresenta Auschwitz para a compreensão de nossa modernidade esclarecida, significação esta que Adorno foi um dos primeiros a acusar. Sob o pano de fundo dessa convergência temática existente entre os dois pensadores, empreende-se aqui uma apreciação das críticas que Agamben endereça à filosofia de Adorno. Seria justo recriminar a dialética negativa adorniana por não ter sido capaz de se libertar do pendor idealista da dialética hegeliana? Seria justo censurá-la por ter sucumbido a uma espécie de estetização do messianismo, como sentencia Agamben? Essas questões são respondidas em defesa de Adorno.

Palavras-chave Dialética; Imagem; Messianismo; Adorno; Giorgio Agamben

ABSTRACT Giorgio Agamben is, nowadays, one of the most intriguing thinkers. In a great extent of his philosophical essays he exploits the exceptional signification of Auschwitz for the understanding of our clarified modernity, and whose signification Adorno was one of the first to accuse. Under the

* Instituto de Filosofia e Ciências Humanas / UNICAMP. Artigo recebido em setembro de 2006 e aprovado em março de 2007.

KRITERION, Belo Horizonte, nº 115, Jun/2007, p. 183-201. 
background of such thematic convergence which is between the two thinkers, here we evaluate Agamben's criticisms of Adorno's philosophy. Would it be fair to condemn the Adornian negative dialectics because it could not get rid of the idealistic tendency of Hegelian dialectics? Would it be fair to censor it for having succumbed to a sort of aesthetic bias of messianism, as Agamben claims? Such questions are answered in defense of Adorno.

Keywords Dialectics; Image; Messianism; Adorno; Giorgio Agamben

Nichts kann unverwandelt gerettet werden, nichts, das nicht das Tor seines Todes durchschritten hätte. ${ }^{1}$

Adorno

Adorno foi um dos primeiros a acusar a significação excepcional que possui Auschwitz para a história da civilização ocidental, significação que aponta para sua atualidade mais flagrante. Com lucidez e clarividência impressionantes, compreendeu ele que Auschwitz emerge como paradigma por excelência de nossa modernidade esclarecida, o do campo de segregação.

Ora, é precisamente esse tema, segundo o qual Auschwitz vem evidenciar de maneira insofismável o nómos oculto da civilização ocidental, que Agamben explicita e desenvolve na terceira parte ("O campo como paradigma biopolítico do moderno") de seu livro Homo sacer: o poder soberano e a vida nua I. Em vez de se deter nos campos (quer de concentração, quer de extermínio) como o local onde se realizou a condição inumana mais absoluta que teve lugar na face da Terra, Agamben se pergunta antes: o que é um campo? Qual sua estrutura jurídica-política? Por que semelhantes eventos puderam nele ocorrer? É esse questionamento que o leva a olhar o campo não como um fato histórico e uma anomalia atinente ao passado, mas sim "como a matriz oculta, o nómos do espaço político em que ainda vivemos". ${ }^{2}$

É certo que, depois de Auschwitz, o campo não mais se materializa numa circunscrição precisa, bem situada e delimitada. O campo como estado permanente de exceção, no qual a lei é suspensa e o indivíduo, despojado de toda humanidade, apresenta agora uma localização deslocante, em que toda forma de vida e toda norma podem ser virtualmente capturadas: "O campo

1 "Nada que não se transmute pode ser salvo, nada que não tenha atravessado a porta de sua morte."

2 AGAMBEN. Homo sacer: o poder soberano e a vida nua I, p. 173. 
como localização deslocante é a matriz oculta da política, que devemos aprender a reconhecer através de todas as suas metamorfoses, desde as zones d'attente de nossos aeroportos até a certas periferias de nossas cidades."’3

Agamben, portanto, não se reporta ao campo de concentração de Auschwitz como um acontecimento histórico e determinado restrito ao passado. Tal como para Adorno - que certa vez escreveu que toda nossa existência deveria ser vista como campo de concentração ${ }^{4}-$, Auschwitz se apresenta para Agamben como paradigma de tantos outros campos que pontuaram e continuam pontuando a história ocidental, campos em cuja circunscrição, atualmente cada vez mais imprecisa e deslocante, uma vida nua se põe à completa mercê de um poder biopolítico soberano. O mesmo vale para a figura do Muzelmann. Esses habitantes espectrais dos campos de concentração alemães da Segunda Grande Guerra, essas figuras apagadas no corpo e na alma a flutuar entre a vida e a morte, que tão pequena atenção receberam até hoje por parte da historiografia dos campos, constituem, para Agamben, bem mais que uma categoria de personagens singulares de nossa lúgubre história recente. Pois eles constituem o paradigma por excelência desta vida nua a habitar os campos, de ontem e de hoje, em que um poder biopolítico se exerce. Não por outra razão, Agamben se empenha por retirálos do lugar marginal e obscuro que ocupam em nossa história e colocá-los no centro da cena, à luz da ribalta. Afinal, a figura do muçulmano evidencia com toda crueza a ambição suprema e inconfessa de uma biopolítica: a completa e consumada dissociação ser fisiológico/ser dotado de logos (ou ainda animal/ homem, zoèlbios). Dissociação que também se patenteia em outras figuras a ele assemelhadas.

Assim como os "muçulmanos", são também exemplares desta vida nua, capturada na esfera de agenciamento e controle total de uma biopolítica, as VP (Versuchepersonen), cobaias humanas tomadas dos campos para experimentos científicos, os pacientes em coma terminal, cujas funções vitais se mantêm às custas de aparelhos, qual banco de órgãos à espera do momento do transplante para doação. ${ }^{5}$ Como casos extremos, "muçulmanos", cobaias humanas e

3 AGAMBEN. Homo sacer: o poder soberano e a vida nua I, p. 182. Ao ler estas linhas, pergunto-me se Agamben tem clara consciência do quanto a realidade atual das favelas brasileiras (e não só delas) se configura perfeitamente como campo: estado permanente de exceção no qual a lei é suspensa e o indivíduo despojado de toda humanidade; do quanto é mesmo impossível deixar de reconhecê-las como campo há muito tempo.

4 "Becket reagiu da única maneira que convém frente à situação do campo de concentração, que não designa, como se estivesse sob o interdito de representá-lo. O que quer que seja é como o campo de concentração [Was ist, sei wie das Konzentrationslager]." (ADORNO. Gesammelte Schriften, v. 6, p. 373; trad. espanhola Dialéctica negativa, p. 380).

5 Cf. AGAMBEN. Ce qui reste d'Auschwitz, p. 169-171 (§ 4.9). 
pacientes em coma terminal mostram-se exemplares no intuito de evidenciar o princípio reinante na esfera biopolítica de captura de uma vida nua, esta vida matável e insacrificável, isto é, cuja morte não configura homicídio nem tampouco celebração de sacrifício. Princípio amiúde escamoteado, mas que se encontra atuante, em maior ou menor grau, nos inúmeros "campos" erigidos pelo Ocidente em nossa história mais recente, em que se confinam favelados, refugiados, populações inteiras de excluídos, vegetando à margem do sistema de capitalismo global, quando não submetidas a uma intervenção militar "humanitária".

A propósito da disjunção supracitada entre ser fisiológico e ser dotado de linguagem -tão reiterada por Agamben como desígnioúltimo de umabiopolítica -, seria preciso contemplá-la à luz da história da metafísica ocidental tal como concebida por Heidegger, uma história orientada pela abstração idealista de toda materialidade viva e corpórea, cuja ambição última teria sido, desde o princípio, a consumação do espírito como substância separada, abstraída de todas as formas concretas de vida. Disjunção que faria figurar, de um lado, a loquacidade sobranceira e doadora de sentido de todo espiritual; de outro, a materialidade corpórea surda e inexpressiva, ou relegada à insignificância e à passividade. Disjunção que ainda podemos reconhecer desdobrada na figuração, de um lado, de um corpo político instituído ou constituído pelo ser de relação (ou dotado do poder de relação); de outro, do indivíduo isolado como corpo fisiológico pura e simplesmente, segregado do corpo político e destituído de voz ativa ou expressão.

A este respeito, a consonância com as formulações que encontramos na Dialética do esclarecimento de Adorno e Horkheimer, notadamente as relativas à denegação de nossa natureza animal, é de fato extraordinária. Temos mesmo, por vezes, a impressão de estarmos lendo Adorno, mais precisamente o Adorno materialista dialético afeito a Benjamin, numa nova terminologia.

Pensemos, por exemplo, na idéia de uma "máquina antropológica ocidental", que é como Agamben designa esta sistemática (e fatídica) operação do logos racional de que se encontra cativa toda metafísica ocidental, operação lógica de distinção promovida pelo conceito na apreensão da identidade que implica, ao mesmo tempo, segregação do não-idêntico, criando cesuras e disjunções - homem/animal, natureza/cultura, vivente/falante, logos/voz. Operação que, assim fazendo, produz e reproduz inevitavelmente zonas de exceção, as quais acabam por se tornar a regra. Em duas palavras, a máquina antropológica ocidental, ao mesmo tempo em que promove a identificação do humano, produz a segregação do animal-inumano, num processo sistemático e reiterado que termina recaindo na absoluta indistinção animal-humano, 
patente como nunca dantes no cenário de Auschwitz. ${ }^{6}$ Ora, tal formulação não lembra deveras o Umschlag dialético do esclarecimento que recai no mítico, a humanidade na animalidade, a cultura na barbárie? De fato, reencontramos desenvolvida em Agamben, certo que com outra terminologia, mais poética e menos dialética, a emblemática sentença da Dialética do esclarecimento, "o mito já é esclarecimento e a modernidade esclarecida recai no mítico". Assim, quando lemos que "toda Lichtung é desde o princípio uma Nichtung", ${ }^{7}$ são os ecos daquela sentença que reverberam nas palavras de Agamben.

Pois, tal como enunciado na Dialética do esclarecimento, a afirmação da identidade humana funda-se no princípio de simultânea apreensão (da essência humana) e exclusão (da natureza animal). Na exata medida em que opera mediante um processo sistemático de capturas e segregações que como tais não se tomam (posto que se põem como apreensão da essência, esclarecimento da identidade mais própria), tal "máquina antropológica" termina por não reconhecer que toda identificação por ela promovida configura uma simultânea aniquilação do que se viu excluído em nome da identidade imposta. Consequientemente, a clara distinção por ela definida está sempre a abrir zonas de exceção, as quais acabam por recair na total indistinção homemanimal.

\section{Imagem e dialética}

Ora, bem me parece que podemos ler boa parte dos ensaios de Agamben como um exercício de construção de imagens dialéticas, de inspiração assumidamente benjaminiana, que busca acompanhar, ao longo da história de nossa civilização, tal fatídico proceder da "máquina antropológica ocidental", a qual, obcecada pela clareza do logos, mergulha a humanidade nas trevas da mais rematada falta de distinção. Pois o que as imagens dialéticas assim configuradas intentam captar é algo que não é nem humano nem animal, algo que figura numa zona de indistinção a cada nova distinção do humano promovida, em diferentes momentos da história da cultura, pela operação de sua "máquina antropológica". Tais imagens buscam, pois, dar a ver este algo para o qual não temos nome e que não somos capazes de definir claramente, posto que se põe entre homem e animal, numa zona de indistinção. Claro está

6 Cf. AGAMBEN. L'Ouvert: de l'homme et de l'animal, notadamente o § 9 ("Machine Anthropologique", p. 52-61), muito embora todo o livro trate do tema.

7 Como lemos em L'Ouvert: “É precisamente porque o mundo só se desvela ao homem pela suspensão e pela captura da vida animal, que o ser se encontra desde o princípio trespassado pelo nada, que toda Lichtung é desde o princípio Nichtung" (p. 120). 
que este algo encontra sua imagem paradigmática e exemplar na figura do muçulmano. Isto é, nesta figura que se apresenta, com efeito, como mortovivo, como um ser cuja vida não é verdadeiramente vida, ou como um ser cuja morte não pode ser declarada morte. Nesta figura, enfim, em que se consuma a inscrição na vida de uma zona morta e, na morte, de uma zona viva. ${ }^{8}$

As imagens dialéticas configurar-se-iam, destarte, a partir de um procedimento não lógico (isto é, não na forma de distinções dicotômicas próprias de identificações classificatórias), mas sim analógico, bem expresso através de figuras bipolares e tensionais da forma nem $A$, nem $B$ (entendamos: nem homem, nem animal; nem morto, nem vivo, etc.), em que os termos opostos, compreendidos como dois pólos de uma mesma tensão dialética, perdem sua identidade própria. ${ }^{9}$ Consumada nessa oscilação insolúvel entre termos opostos, a imagem dialética desenharia, necessariamente, uma figura de ambigüidade, correlata a uma suspensão de sentido, suspensão esta posta no horizonte de uma futura doação de sentido. Tais imagens dialéticas são ainda descritas por Agamben como "imagens móveis de um ser de passagem", destarte capazes de captar a ambivalência latente entre os dois pólos do humano, quais sejam, ser vivente e ser dotado de linguagem.

Encontra-se latente aqui um momento utópico-messiânico, notemos, prefigurado por este gesto de tornar inoperante a máquina antropológica, deixando sem efeito as categorias dicotômicas por ela sistematicamente rearticuladas como resultado de uma dinâmica de poder. No momento em que suas categorias viessem a perder sua razão de ser, a relação homem-natureza deixaria de ser marcada pela dominação do natural pelo humano - ou melhor, deixaria de ser marcada pela dominação pura e simplesmente, uma vez que as categorias do humano e do animal mergulham hodiernamente na mais absoluta indistinção. Então, homem e animal viriam a figurar numa relação ociosa, cujo paradigma seria o do deleite conseqüente à consumação do prazer. ${ }^{10}$

Isso tendo sido dito como apresentação da ensaística agambeniana e de sua relação com a dialética do esclarecimento ocidental, gostaria de me reportar a uma das recriminações que Agamben endereça à dialética adorniana (mais

8 Cf. AGAMBEN. Ce qui reste d'Auschwitz, p. 88.

9 Sirvo-me aqui da exposição que faz Agamben das imagens dialéticas benjaminianas presente na sexta parte do ensaio "Nymphae". Cf. AGAMBEN. Image et mémoire, p. 50-52.

10 Cf. AGAMBEN. L'Ouvert: de l'homme et de l'animal, p. 127-138 (§ 19 e § 20). 
adiante tratarei de uma segunda recriminação com esta relacionada). Segundo essa recriminação, a filosofia adorniana não teria admitido aquela ambigüidade essencial às imagens dialéticas benjaminianas, ou não teria suportado a ambigüidade perturbadora de tais imagens dialéticas, em função de um pendor idealista que ela não pôde deixar de acalentar. No fundo, ela teria sido incapaz de se libertar da noção hegeliana de dialética. Escreve Agamben:

O que Adorno parece não compreender, ao tentar em última análise remeter a dialética a sua matriz hegeliana, é que o essencial, para Benjamin, não é o movimento que conduz a Aufhebung da contradição através da mediação, mas o momento de suspensão, no qual o próprio termo de mediação vem a ser exposto como zona de indiferença entre dois termos opostos, zona como tal necessariamente ambígua. ${ }^{11}$

Para uma boa compreensão desse posicionamento de Agamben francamente favorável às imagens dialéticas benjaminianas, tal como ele as entende, ao mesmo tempo em que contrário à dialética adorniana, não podemos deixar de recorrer a um ensaio de sua autoria consagrado justamente ao problema do método em Adorno e Benjamin. Trata-se do ensaio "Le prince et le crapaud: le problème de la méthode chez Adorno et Benjamin", que integra a coletânea Enfance et histoire. ${ }^{12}$ A partir de um trabalho de leitura e interpretação da já célebre troca de correspondências ocorrida entre os amigos na segunda metade da década de 1930, na qual aflora a referida desavença metodológica, Agamben acusa a impostura teórica, como se lhe afigura, em que incorre Adorno na defesa das categorias hegeliano-marxistas de mediação e totalidade.

Retomando a recriminação que Adorno dirige então contra Benjamin, segundo a qual sua "dialética", carente da devida "mediação pelo processo global", situar-se-ia na encruzilhada enfeitiçada de magia e positivismo, Agamben observa, com boa dose de perspicácia, que o espectro que tanto atormenta Adorno nestas formulações - a admissão tácita de uma relação de fato causal por falta de mediação dialética - ronda antes sua própria concepção de dialética, daí a necessidade encarniçada que demonstra de exorcizá-lo. Assim é que a alardeada "mediação dialética pelo processo global" tão reclamada por Adorno talvez não faça mais que salvar as aparências de um determinismo (no fundo causal) pressuposto, mas não assumido, na sua própria concepção dialética da relação entre a superestrutura cultural (domínio da produção espiritual) e a estrutura econômica (domínio da reprodução material).

11 AGAMBEN. Image et mémoire, p. 52.

12 Cf. AGAMBEN. Enfance et histoire: destruction de l'expérience et origine de l'histoire, p. 187-215. 
Com efeito, a acusação de um determinismo implícito só faria sentido para uma dialética que, à semelhança da hegeliana, continuasse a operar com as distinções metafísicas correlatas à distinção material/espiritual, tal como a disjunção entre estrutura econômica e superestrutura cultural. Ora, para Agamben, este seria o caso da dialética adorniana, incapaz de se libertar do pendor idealista da dialética hegeliana, mas não seria seguramente o caso das imagens dialéticas benjaminianas que, à semelhança do que ocorre na reflexão de Marx, almejam apreender a interpenetração do material e do espiritual tal qual consumada na práxis:

O farisaísmo que implica a separação entre estrutura econômica e superestrutura cultural permanece intacto se se faz do processo econômico a causa determinante que a mediação se encarrega depois de recobrir pudicamente [e pacientemente, poderíamos acrescentar, lembrando a paciência hegeliana do conceito] mediante seu véu dialético. $\mathrm{O}$ único materialismo verdadeiro é aquele que suprime radicalmente esta separação, sem jamais considerar a realidade histórica como a soma de uma estrutura e de uma superestrutura, mas como unicidade imediata dos dois termos na práxis. ${ }^{13}$

É esta indistinção consumada na práxis entre os domínios espiritual e material que, segundo Agamben, as imagens dialéticas benjaminianas almejariam contemplar na configuração de suas constelações, à diferença das concepções dialéticas de matriz hegeliana, cujo idealismo enrustido ainda carregaria o ônus das distinções metafísicas da ordem do material/espiritual (homem/animal, ser vivo/ser dotado de linguagem, vida biológica (zoè)/“forma de vida" (bios), estrutura econômica/superestrutura, etc.).

Ora, tal recriminação dirigida à filosofia adorniana porta, a meu ver, uma tremenda dose de injustiça, posto que desabona, duma só penada, toda crítica acerba e pertinaz que o próprio Adorno endereça a Hegel no esforço de elaboração de sua dialética negativa. ${ }^{14}$ Seja como for, se é certo que Adorno e Agamben compartilham, em linhas gerais, a caracterização da fatídica reviravolta dialética do esclarecimento como consumação dos desígnios últimos da metafísica ocidental, o mesmo talvez não se possa dizer da reflexão filosófica (ainda dialética?) elaborada por cada um deles com o expresso propósito de se libertar daquela fatídica dialética, ou ao menos de não compactuar com ela, rompendo o feitiço de que se encontra cativa. 
Agamben, quanto a ele, concede ao momento imagético da linguagem um privilégio ímpar na expressão do horror inconcebível estampado na face da civilização ocidental por Auschwitz, tomado como paradigma exemplar de tantos outros campos a ele assemelhados persistentes em nossa história. Privilégio outorgado à expressão artístico-poética pela virtude de dar voz à surda mutilação que sustenta a abstrata uniformidade do mundo tecnocrático hodierno. No limite, privilégio concedido à imagem artística pela capacidade de fazer ressaltar, nos traços de normalidade do existente, a caricatura grotesca de Auschwitz, do mesmo modo que a literatura de Kafka, para citar um exemplo, foi capaz de prefigurar de forma assombrosa a realidade dos campos de concentração. Privilégio este correlato, evidentemente, a uma desconfiança bem nietzschiana perante todo silogismo da razão, toda cabriola dialética, sobretudo em vista da realidade do campo, que volta a emergir com violência assustadora em nossos dias aqui e ali. Compreendemos, nesses termos, o procedimento de que amiúde se serve Agamben e que consiste em recorrer a um caso extremo, ou limite, como imagem exemplar de um processo sistematicamente escamoteado na normalidade da existência. A imagem do caso singular e excepcional busca iluminar o que via de regra se oculta na normalidade da existência, sobretudo quando, como ocorre em nossos dias, o caso excepcional tende a tornar-se a regra, confundindo-se com ela num permanente estado de exceção. ${ }^{15}$

De maneira notável, assim, a escritura de Agamben realiza a confluência do momento conceitual com o momento imagético-expressivo. Seus ensaios florescem, com efeito, naquela região de limiar em que o texto filosófico não mais se sabe distinguir da obra artístico-literária; é nesta região intervalar que medram e desabrocham. Ora, não recriminaria Adorno, na ensaística de Agamben, esta dissolução, que nela se leva a termo, das fronteiras que delimitam os âmbitos de competência do conhecimento racional e da expressão artística? Não argumentaria ele que seus ensaios "filosóficos" teriam se rendido ao momento retórico da linguagem, em detrimento do momento de elaboração conceitual?

Sim, porque, para Adorno, o domínio da filosofia não se equipara ao âmbito estético, nem tampouco com ele se confunde. Com efeito, muito embora em seus primeiros escritos, que denotam forte influência de Benjamin, Adorno tenha

15 Notemos, de passagem, que não está ausente também na filosofia adorniana uma vertente hiperbólica correspondente a um exagero deliberado na exposição. Tal momento retórico do exagero nela se afigura necessário para lograr expressar a enormidade, tornada sempre razoável, da realidade em questão. Ou melhor, digamos que sua exposição se ressente, por vezes, de uma iluminação desmedida no intuito de esclarecer uma existência obcecada pelo ferrenho senso de media de sua razão. 
advogado uma imbricação de elementos artístico-filosóficos (assim, por exemplo, na noção de imagem dialética formulada em sua tese sobre Kierkegaard), sua obra posterior termina decididamente por recusar tal ambigüidade mantida por Benjamin, delimitando dois âmbitos distintos de competência: de um lado, o da dialética conceitual, de outro, o da imagem estética - sem que a afirmação de tal disjunção, é bom que se diga, tenha revogado a mútua e fecunda participação do conceitual no mimético, que continua sendo sumamente apreciada por Adorno. Desse modo, a reapreciação do elemento retórico e sensual do conceito, de um lado, bem como do distanciamento reflexivo atuante na mimese artística, de outro, são exigências que não devem redundar, para Adorno, na dissolução dos limites próprios de cada esfera de competência. ${ }^{16}$

Compreendemos destarte que se a atenção micrológica advogada pela dialética adorniana a tudo que se mostra insignificante e inexpressivo aos olhos do conceito se faz, é certo, em favor do momento mimético, ela não se faz, em contrapartida, em detrimento da elaboração conceitual. A teoria capaz de fazer justiça ao mais ínfimo e desprezível não é, certamente, uma teoria propensa a abrir mão de si mesma, ante a matéria sensível, em nome da apreensão mimética ou imagética pura e simples; muito menos uma teoria feita de declamações de boas intenções e sentimentos para com o desprezado pelo conceito. Não se perfaz sem trabalho do conceito, sem esforço conceitual, uma teoria capaz de corresponder ao apelo exercido pela matéria sensível e corpórea, e, assim, reconhecer como significativo o que foi desprezado como insignificante pelo próprio conceito. Pois é somente uma conversão do olhar teórico - não sua renúncia - que pode tornar relevante o que até então aparentava ser desprezível e insignificante. Eis a crítica adorniana que, segundo creio, acerta em cheio a postura de Agamben. Condena-se à impotência uma teoria que renuncia a si mesma em prol da imagem mimética, almejando, na melhor das intenções, acolher o momento de prazer e dor tornado inexpressivo pela apropriação conceitual. Somente no seio de uma nova configuração ou constelação teórica, aquilo que era relegado como inexpressivo e irrelevante pode vir a ganhar uma significação até então insuspeita, tornando-se então digno de atenção e interpretação. ${ }^{17}$

16 O impedimento da pseudomorfose entre os domínios da mimese e do conceito é, para Adorno, o que assegura a persistência do fecundo campo de tensão preexistente entre o âmbito da arte e o da filosofia, traduzido nos termos da verdade que busca pela expressão e da expressão que anseia pela verdade. No primeiro estudo da tese A Filosofia, a Arte e o Inominável desenvolvo mais extensamente este tema. Ver, especialmente, a segunda parte, "A dialética levada a termo", do primeiro estudo.

17 Cf. notadamente GAGNEBIN. Divergências e convergências metodológicas sobre o método dialético entre Adorno e Benjamin. 
Não obstante a pertinência dessa argumentação, seria preciso ainda se perguntar se tal reorientação do olhar teórico não deve seu impulso germinal precisamente à reapreciação da relevância da componente mimética - e isto em favor de uma leitura da Dialética negativa atenta à primazia que ela não deixa efetivamente de conceder à componente mimética, e que corresponde exemplarmente à invocação de Agamben por uma dialética "liberada de toda abstração". O apelo exercido pelo micrológico, a atenção concedida ao momento somático de prazer e dor, não se encontra efetivamente na raiz da exigência por uma nova e redentora constelação conceitual capaz de lhe fazer justiça? Uma indagação como essa, que faz inverter os termos da questão deixando-a em suspenso, é bem própria da dialética negativa adorniana.

A esse respeito, a ambigüidade é de fato notável, e não procura ser dirimida em momento algum por Adorno - o que parece escapar inteiramente a Agamben. Uma leitura atenta do último aforismo de Minima Moralia seria para tanto proveitosa. A filosofia só faz jus a um ponto de vista redentor, lemos ali, na medida em que se abre à perspectiva das próprias coisas em sua indigência imanente (e não quando apela para o transcendente); na medida em que logra "produzir perspectivas nas quais o mundo venha a se mostrar em suas alienações, em suas feridas e em suas fraturas, tal como um dia, indigente e deformado, aparecerá à luz messiânica". ${ }^{18}$ Destarte, essas perspectivas efetivamente redentoras não derivam da reelaboração teórica pura e simples executada como que a partir de si mesma, mas sim do contato mais vivo com os objetos. Do contato resultante - porque não dizer? - de um abandono mimético, de uma entrega sensível aos objetos, subtraído da violência exercida pelo conceito. Não é exclusivamente de si mesma que a dialética extrai sua força redentora de iluminação (donde vemos desde já que Agamben se equivoca redondamente quando critica a dialética adorniana por recair em mera contemplação teórico-estética da redenção), mas do contato com as próprias coisas: sua luz promana concomitantemente dos objetos, cujo anseio pela redenção ela contempla. Numa formulação algo retórica, que procurasse dar conta dessa ambigüidade insolúvel, poderíamos dizer que tal constelação teórica esclarece por amor das próprias coisas mortificadas, cujo brilho não de todo extinto ela logra captar.

Penso que seja o bastante para fazer ver a extrema e crucial relevância que possui o momento materialista para a dialética negativa adorniana, e, por conseguinte, o quão injusta se afigura a recriminação formulada por Agamben, 
que nela acusa um renitente e comprometedor pendor idealista. Passemos, então, para a segunda recriminação que Agamben dirige a Adorno.

\section{Esteticismo e messianismo}

A certa altura de seu comentário sobre a Epístola de S. Paulo aos Romanos, Le temps qui reste, Agamben endereça à filosofia de Adorno uma crítica de outra ordem - muito embora, como veremos, relacionada com a anterior. Segundo essa crítica, a dialética adorniana teria recaído numa estetização do messianismo. Retomemo-la em rápidas pinceladas, no intuito de evidenciar seu fulcro, qual seja, a perda de identidade a que se inclina o sujeito verdadeiramente messiânico.

Escreve ali Agamben: "Apesar das aparências, a dialética negativa é um pensamento que não é de forma alguma messiânico, e que se encontra mais próximo da tonalidade afetiva de um Jean Améry que de Benjamin."19 A tonalidade afetiva a que se refere Agamben nesta passagem não é outra senão a do ressentimento, aquela para a qual tudo o que aconteceu, conquanto contingente, assume o caráter de algo irreparável. Claro está que este "tudo o que aconteceu" alude muito particularmente aqui à eclosão da Segunda Grande Guerra (carregando em suas entranhas o horror inominável da Shoah) em lugar da acalentada emancipação da humanidade para a qual a filosofia adorniana, assim como toda filosofia materialista de filiação marxista, acreditava contribuir decidida e ativamente com sua reflexão sobre a práxis revolucionária.

A filosofia teria estado então prestes a se realizar, mas o momento de sua realização se perdeu, e definitivamente. Agamben corrobora tal apreciação lembrando a famosa sentença do início da Dialética negativa: "A filosofia sobrevive porque falhou o momento de sua realização." Contingente e irreparável ao mesmo tempo, o acontecimento histórico fatídico teria marcado de forma indelével a filosofia adorniana, colocando-a sob o signo da impotência. A emancipação da humanidade, antes considerada uma possibilidade concreta inscrita na história, passa a ser vista como aparência nunca realizável. Nesse sentido, seria sintomática a frase final do último aforismo de Minima Moralia, de que se serve Agamben para corroborar sua tese, segundo a qual: "a própria questão sobre a realidade ou a irrealidade da redenção se torna praticamente 
indiferente" 20 . Desde então, Adorno teria procedido a uma estetização do messianismo sob a forma do comme si. O que quer dizer que à sua filosofia (ou à filosofia em geral) teria restado apenas contemplar eternamente as coisas tais como elas se apresentariam do ponto de vista da redenção. "É o fato de ter perdido o momento de sua própria realização que obriga a filosofia a contemplar ad infinitum a aparência de redenção. A beleza estética é, por assim dizer, o castigo que a filosofia deve sofrer por ter faltado com sua realização.”21

Para que fizesse justiça a um autêntico messianismo, teria faltado à filosofia adorniana um gesto capaz de quebrar o sortilégio que a condena a tão-só contemplar, impotente, o mundo sob a luz de uma redenção sempre aparente. Mas que gesto de potência seria este? Nenhum outro senão aquele gesto paradoxal evocado pela famosa sentença pauliniana que Agamben toma por divisa: o gesto de potência que se consuma na impotência, ou no assentimento da impotência. E aqui, sim, nos acercamos do ponto nevrálgico desta crítica dirigida a Adorno por Agamben. Afinal, a renúncia à realidade da redenção não se deve propriamente à estetização do messianismo, visto que a estetização, ela própria, se deve a uma falta anterior, característica de um temperamento propenso ao ressentimento, que Agamben acusa expressamente quando afirma que Adorno não abre mão das pretensões identitárias e das prerrogativas do sujeito. É com este sujeito aferrado a si mesmo e a suas representações que o messianismo pauliniano intenta ajustar contas por meio de seu comme non. A vocação messiânica, enfatiza Agamben, solapa e anula antes de tudo o sujeito: "A vinda do messias significa que todas as coisas - e, com elas, o sujeito que as contempla - são capturadas no comme non, evocadas e revogadas no mesmo movimento." 22

$\mathrm{O}$ sujeito autenticamente messiânico não pode pretender contemplar o mundo à luz da redenção apegado a suas representações, entre as quais se incluem, certamente, aquelas produzidas por uma dialética idealista como a de Hegel, de que Adorno, segundo Agamben, não teria conseguido se libertar completamente. Não, o sujeito autenticamente messiânico só contempla o mundo redimido na medida em que ele próprio se perde no que pode ser redimido: "o sujeito que pretende salvaguardar-se e manter-se infinitamente

20 Retomaremos logo mais adiante esta frase em favor de Adorno. Desde já, porém, gostaria de assinalar que esta caracterização feita por Agamben de uma obra fraturada de forma irreparável pela eclosão da Guerra em lugar da revolução poderia se aplicar, ainda que com certas ressalvas, à obra de Horkheimer, mas dificilmente se sustentaria no caso de Adorno. Ver, a propósito, o artigo de HABERMAS. Bemerkungen zur Entwicklungsgeschicht des Horkheimerschen Werkes.

21 AGAMBEN. Le temps qui reste, p. 68.

22 AGAMBEN. Le temps qui reste, p. 74. 
a salvo na aparência da redenção perde a partida quando contempla a própria ruína" ${ }^{23}$. O gesto genuinamente messiânico deve, assim, atender a um impulso de dessubjetivação, de perda de si mesmo em nome do outro, ou de tantos outros, oprimidos e sacrificados pela marcha da história. Esse gesto só se perfaz, portanto, mediante a derrocada da subjetividade pretensamente autárquica e soberana, derrocada solidária a toda massa de criaturas injustiçadas na história, e não (como alfineta Agamben) por meio da construção de um discurso engenhoso e bem pensado (como o da dialética adorniana!) capaz de estimar e registrar a perda. ${ }^{24}$

A dialética adorniana, em suma, não faria jus a uma vocação verdadeiramente redentora, segundo Agamben, por não consentir com esse movimento de dessubjetivação - movimento que deve presidir não só o gesto verdadeiramente messiânico, mas também, seja dito de passagem, a concessão de voz ao outro, própria do autêntico testemunho, como noção inaugural de uma nova ética.

Em vista deste breve apanhado da crítica agambeniana à estetização do messianismo, caberia desde logo indagar até que ponto a desavença aqui existente entre Adorno e Agamben-Benjamin não se prenderia a esta confiança, que Adorno julgaria certamente demasiada, depositada na perda de identidade e de autonomia do sujeito hodierno - a qual, aliás, o próprio processo histórico leva a termo, em conformidade com aquela dialética mencionada anteriormente. Caso em que a crítica seria recíproca. De sua parte, Adorno recriminaria o gesto agambeniano afeito à dessubjetivação, ou à derrocada das pretensões identitárias do sujeito, como um gesto de abandono às potências míticas, uma vez que no seu cumprimento o sujeito abriria mão definitivamente do distanciamento crítico-reflexivo (tão prezado por Adorno) somente graças ao qual lograria ele cobrar consciência da falsa identidade assumida na totalidade social, visando à realização de uma autêntica figura de identidade que superaria a alienação vigente.

Nisso nos faria crer, com efeito, uma leitura simplista da obra adorniana. Porém, uma leitura rigorosa e atenta, especialmente de sua obra tardia, revela-nos que é bem mais elaborado do que se costuma supor o tratamento dispensado a essa questão. Como procuraremos mostrar a seguir, a exposição de Adorno a esse respeito, se não avaliza inteiramente a posição defendida por Agamben, mostra-se surpreendentemente avizinhada a ela. 
O sujeito crítico reclamado por Adorno não deixa de ser o indivíduo, é certo, mas não o indivíduo no sentido tradicional, isto é, o indivíduo burguês nascido como garante das práticas de mercado, cuja "autonomia" tão-só reproduz os requisitos do liberalismo econômico - e cuja capacidade de livre autodeterminação já não passa, em nossos dias, de ficção extrema e desesperada. É nesse sentido que o sujeito crítico adorniano cumpre um papel distinto daquele desempenhado pelo sujeito transcendental kantiano, e também pelo empírico. Pois a doutrina de Kant (e também, num certo sentido, a de Freud) sustentou o pressuposto teórico de identidade e autonomia do indivíduo comprometido com a práxis social capitalista. Para Adorno, em contrapartida, o sujeito efetivamente crítico é aquele - e só aquele - que se mostra capaz de renunciar a esta autonomia de cunho marcadamente liberal. Ele é, fundamentalmente, indivíduo capaz de se abrir à experiência que se encontra interditada na totalidade social dominada pela frialdade burguesa. Seu diferencial seria, portanto, a capacidade de padecer perante a exterioridade empírica da sociedade, de fazer a experiência doída de sua insignificância: esta é "a pedra de toque, o motor da mediação necessária para romper o feitiço da identidade". ${ }^{25}$

Paradoxalmente, assim, é só através da renúncia ao imperativo concorrencial e à exigência de identidade e autonomia que o existente lhe impinge, ou da renúncia ao ferrenho imperativo de autoconservação (mediante o acolhimento de sua própria morte, num gesto de antecipação da morte que o mercado lhe destina), ${ }^{26}$ que, em Adorno, o indivíduo, enquanto sujeito de reflexão crítica, lograria deixar de ser mero reflexo das práticas de mercado, retomando a consciência do processo histórico de modo a intervir na práxis - e reconquistando destarte uma verdadeira autonomia, poderíamos acrescentar.

Mas por onde apanhar esta existência individual tornada espectral, fantasmagoria abstrata aferrada em si mesma, como algo de mítico? Questão cuja resposta poderia talvez formular sumariamente nos seguintes termos: tal experiência só se mostra acessível, para Adorno, no único vestígio de individualidade ainda remanescente, vale dizer, na experiência do sofrimento e da finitude, que abre caminho para a expressão. Ao contrário de sustentar uma pretensa identidade e aferrar-se a uma ilusória autonomia, o sujeito crítico reclamado por Adorno é o que logra acolher sua diferença e heteronomia, o que significa, ser capaz de ser afetado pelos objetos fazendo a experiência de sua

25 RIUS. Theodor W. Adorno: del sufrimiento a la verdad, p. 55. Valho-me aqui deste belo estudo de Mercè Rius sobre a obra de Adorno, infelizmente pouco conhecido.

26 Ver, a respeito, o terceiro estudo já mencionado da tese A Filosofia, a Arte e o Inominável. 
morte. ${ }^{27}$ Desse modo, numa passagem notável da Dialética negativa, Adorno assevera ser a aceitação da finitude a condição necessária para libertação de uma existência empedernida, cegamente aferrada na autoconservação, assim como para redenção de um espírito cativo do sortilégio de ser eterno: "Nada que não se transmute pode ser salvo, nada que não tenha atravessado a porta de sua morte. (...) O gesto de esperança consiste em não reter nada daquilo que o sujeito intenta tomar como ponto de apoio, nada daquilo que lhe promete sua duração." 28

\section{Conclusão}

Esta brevíssima reapreciação do pensamento adorniano concernente às pretensões identitárias do sujeito hodierno faz soar em falso, segundo penso, a acusação de "estetização do messianismo" a ela endereçada por Agamben. Mais ainda, a mim me parece que, em certo sentido, a filosofia adorniana leva mais a sério o anseio pela redenção e mostra-se mesmo mais prenhe de esperanças que o messianismo advogado por Agamben. Isto porque o pensamento de Adorno continua fiando-se no poder esclarecedor do logos ocidental, ou melhor, no poder do conceito de, apesar do conceito, voltarse sobre si mesmo no intuito de reconhecer o elemento não conceitual a ele subjacente, acolhendo o momento corpóreo ou somático por ele mesmo renegado em vista da reconciliação. Assim como continua confiando, apesar de tudo, na capacidade de reflexão e distanciamento crítico do sujeito que, como escreve ele, empreende a penosa passagem pela porta de sua morte, isto é, do sujeito que se abre para a dolorosa experiência da cabal heteronomia a que se vê submetido na totalidade administrada.

Quanto a Agamben, não apostaria ele no processo em curso de liquidação do indivíduo autônomo, assim como da racionalidade subjetiva que lhe é solidária, cegamente convencido de que tal derrocada prenuncie necessariamente sua redenção? Não estaria ele, com efeito, imbuído da crença messiânica no advento de uma outra humanidade, a se cumprir no dia em que tiver lugar uma espécie de depuração do logos racional ou discursivo, que seria igualmente sua consumação, com a qual a humanidade ver-se-ia enfim libertada de um logos centrado no sujeito e da inarredável ilusão de verdade que ele encerra? Ou, com outras palavras, não confiaria ele que a redenção tenha lugar no dia em que tanto o sujeito como o logos nele centrado

27 Ver, a propósito, RIUS. Theodor W. Adorno: del sufrimiento a la verdad, p. 56.

28 ADORNO. Gesammelte Schriften, v. 6, p. 384; trad. espanhola Dialéctica negativa, p. 391. 
se consumem renegando-se a si mesmos? Dia este de juízo final, em que o poder da linguagem viria a se voltar contra a própria linguagem, fazendo com que o juízo não mais se realize no domínio do logos ou da linguagem, mas sim sobre a linguagem - linguagem sendo aqui entendida como logos discursivo e também racional, indistintamente. Lemos no ensaio "Idéia do Juízo Final":

O juízo final não é um juízo na linguagem, que como tal jamais poderá ser verdadeiramente decisivo (...). Ele é antes um juízo sobre a linguagem, que na linguagem elimina a linguagem da linguagem. O poder da linguagem deve ser voltado contra a linguagem. O olho deve mirar seu ponto cego. A prisão deve encerrar a si mesma. É o único meio pelo qual os prisioneiros poderão se libertar. ${ }^{29}$

O fato de Agamben, no que designa por "logos ocidental”, confundir as figuras da razão e da linguagem contribui decisivamente, a meu ver, para esta recaída num messianismo negativo. Pois, em virtude desta falta de distinção, ele se encontra impossibilitado de pensar uma outra figura de razão capaz de voltar-se sobre si mesma de outra forma que não a da negação redentora. Como é o caso da proposta adorniana de reapreciação e incorporação do elemento retórico-discursivo, em atenção ao apelo do momento mimético-corpóreo (de prazer e de dor) por parte do logos conceitual, tal qual elaborada na Dialética negativa.

Em sua Dialética negativa, com efeito, Adorno advoga uma noção de dialética atenta à negatividade da sensibilidade segregada no entendimento, vale dizer, atenta à renitência do desejo encadeado no pensamento, assim como à ânsia imorredoura de redenção que habita o que já não tem esperança. A Dialética negativa se avizinha, assim, de uma teoria estética justamente porque se encontra imbuída da esperança, latente no mundo, de que a frialdade reinante possa ceder, despertando a simpatia pelo que sofre.

Como já observamos, o mais relevante para a emancipação do cerrado contexto de ofuscação seria, segundo esta dialética, conseguir captar os vestígios mais desprezíveis deixados no existente, vestígios cada vez mais relegados ao esquecimento pelo progresso do pensamento identificador. Pois não é senão a partir da matéria e das categorias da própria imanência que se poderia vir a expressar o que a transcende. Se ainda se pode falar que a metafísica sobrevive é no instante de sua queda, e não no salto para o absolutamente outro. Assim, o autêntico anseio de transcendência da situação atual é algo que se efetiva no contato mais íntimo com o objeto - por isso mesmo incompatível com o apelo de uma transcendência sacrossanta -, quando se deixa guiar pelo impulso 
expressivo do sujeito. Daí afirmar Adorno que a condição de verdade do pensar filosófico reside na atenção concedida ao momento somático de prazer e dor, ou melhor, na sua capacidade de abandonar-se à eloquiência da dor.

Por-se-iam os ensaios de Agamben à altura de uma concepção tão visceral do pensar filosófico? Não será verdade que, neles, o pensamento, definido pelo próprio Agamben como impulso de apreensão do sofrimento da voz na linguagem, ${ }^{30}$ se encontre cativo do encanto da linguagem, ou do momento imagético da linguagem? Não escapa a Agamben que a dialética adorniana se avizinha de uma teoria estética não porque, teoria distanciada do mundo, só lhe reste a eterna contemplação de uma imagem transcendente de redenção, mas sim porque, teoria entranhada no mundo, intente, ao contrário, contemplar o anseio imorredouro pela redenção que habita o imanente, sensível e corpóreo?

Se, conforme lemos no último aforismo de Minima Moralia, mencionado por Agamben, a questão da realidade ou irrealidade da redenção se apresenta como questão secundária para a dialética adorniana, é porque a questão primeira e fundamental diz respeito à filosofia, e não à teologia, isto é, diz respeito à exigência extrema e mesmo dilacerante imposta à razão para superar a si mesma através de si mesma, entendamos, sem apelar para uma dimensão teológica redentora, asseguradora da redenção. Com outras palavras, a questão de saber se a redenção é acontecimento efetivamente inscrito na existência concreta (neste sentido real) ou, ao contrário, mera imagem desta pobre existência concreta sem remissão (neste sentido aparente), esta questão da realidade efetiva ou não da redenção, dizia, torna-se irrelevante não em si mesma, mas em face do caráter desesperado que assume o esforço da razão para transcender a si mesma sem recorrer ao tranqüilizante e consolador transcendente teológico. Em vista disso, a recriminação feita a Adorno por Agamben bem poderia voltar-se contra ele mesmo. Afinal, é a redenção na qual se crê como realidade efetiva, assegurada de antemão pelo curso da história, que Adorno ajuíza ser uma aparência tão ilusória quanto reconfortante.

\section{Referências Bibliográficas}

ADORNO, T. W. Gesammelte Schriften. Eds. R. Tiedemann; G. Adorno. Frankfurt: Suhrkamp Verlag, 1970-1986. $20 \mathrm{v}$.

. Dialéctica negativa. Trad. José María Ripalda. Madri: Taurus, 1984. (Título original: Negativ Dialektik). 
ADORNO, T. W. Minima Moralia: reflexões a partir da vida danificada. Trad. Luiz Eduardo Bicca. São Paulo: Ática, 1993. (Título original: Minima Moralia. Reflexionen aus dem beschädigten Leben).

. Notas de Literatura I. Trad. Jorge Mattos Brito de Almeida. São Paulo: Duas Cidades/Editora 34, 2003. (Título original: Noten zur Literatur I). AGAMBEN, G. Ce qui reste d'Auschwitz: l'archive et le temoin. Homo Sacer III. Trad. Pierre Alferi. Paris: Rivages, 1999. (Título original: Quel che resta di Auschwitz: l'archivio e il testimone. Homo sacer III. Turim: Bollati Boringhieri, 1998).

. Enfance et histoire: destruction de l'experience et origine de l'histoire. Trad. Yves Hersant. Paris: Payot, 1989. (Título original: Infanzia e storia: distruzione dell'esperienza e origine della storia. Turim: Giulio Einaudi, 1978).

AGAMBEN, G. Homo sacer: o poder soberano e a vida nua I. Trad. Henrique Burigo. Belo Horizonte: Editora UFMG, 2002. (Título original: Homo sacer: il potere sovrano e la nuda vita. Turim: Giulio Einaudi, 1995).

. Idée de la prose. Trad. Gérard Macé. Paris: Christian Bourgois, 1988. (Título original: Idea della prosa. Milão: Feltrinelli, 1985).

1998.

Image et mémoire. Trad. Marco Dell'Omodarme et al. Paris: Hoëbeke,

AGAMBEN, G. L'homme sans contenu. Trad. Carole Walter. Saulxures: Circé, 1996. (Título original: L'uomo senza contenuto: documenti letterari. Milão: Rizzoli, 1970). . Le langage et la mort: un séminaire sur le lieu de la négativité. Trad. Marilène Raiola. Paris: Christian Bourgois, 1991. (Título original: Il linguaggio e la morte: un seminario sul luogo della negatività. Turim: Giulio Einaudi, 1982).

Le temps qui reste: un commentaire de l'Epitre aux Romains. Trad. Judith Revel. Paris: Rivages, 2000. (Título original: Il tempo che resta: un commento alla Lettera ai Romani. Turim: Bollati Boringhieri, 2000).

. L'Ouvert: de l'homme et de l'animal. Trad. Joël Gayraud. Paris: Rivages, 2002. (Título original: L'aperto. Turim: Bollati Boringhieri, 2002).

. Stanze: parole et fantasme dans la culture occidentale. Trad. Yves Hersant. Paris: Christian Bourgois, 1981. (Título original: Stanze: la parola e il fantasma nella cultura occidentale. Turim: Giulio Einaudi, 1977).

CHIARELLO, M. A Filosofia, a Arte e o Inominável: três estudos sobre a dor da finitude na obra de T. W. Adorno. Tese (Doutorado) - Campinas, Unicamp, 2002.

GAGNEBIN, J. M. Divergências e convergências metodológicas sobre o método dialético entre Adorno e Benjamin. In: COLÓQUIO NACIONAL "DIALÉTICA NEGATIVA, ESTÉTICA, EDUCAÇÃO”. Piracicaba: Unimep, mar. 2000. (Mimeo.). HABERMAS, J. Bemerkungen zur Entwicklungsgeschicht des Horkheimerschen Werkes. In: SCHMIDT, A.; ALTWICKER, N. Max Horkheimer Heute: Werk und Wirkung. Frankfurt a. M.: Fischer Verlag, 1986. p. 163-179.

RIUS, M. Theodor W. Adorno: del sufrimiento a la verdad. Barcelona: Laia, 1985. 